\title{
A terror árnyékában
}

\section{MURÁNYI József Ignác ${ }^{1 \oplus}$}

\begin{abstract}
Jelen cikkemben igyekeztem a terrorizmus, kiemelten a radikális iszlám terrorizmus pszichológiai és szociálpszichológiai veszélyeit bemutatni. A témát elsősorban Maslow szükségletpiramisa felöl közelítettem meg, valamint kitértem a terrorizmus által potenciálisan aktiválható elhárító mechanizmusokra is, amit összefüztem a szociálpszichológia nézópontjával. Emellett rövid jellemzést adtam a dzsihád eszméjéről, illetve a terrorizmus közös pszichológiai motívumairól, említést tettem a média szerepéröl, illetve ezek társadalomra gyakorolt hatásairól, kiemelten említve Európát, valamint röviden jellemeztem szervezeti struktúrájukat is. Cikkemet egy rövid személyes gondolattal zárom.
\end{abstract}

Kulcsszavak: terrorizmus, dzsihád, pszichológia, szociálpszichológia

\section{Bevezetés}

A „terror” szó a latin „terrere” szóból származik, amelynek jelentése „megfélemlíteni". Már Szun-ce i. e. 4. század körül élt világhírü kínai katonai stratéga is nagyszerűen összefoglalta egy mondatban a jelenség esszenciáját: „Ölj meg egyet, félemlíts meg tízezret!"2

A terrorizmus és a radikalizálódás korunk egyik legkomplexebb nemzetbiztonsági kihívása. ${ }^{3}$ Definícióját tekintve rengeteg, több száz meghatározást alkalmaznak szakmai berkeken belül. Többek között az FBI a következőképpen határozta meg a terrorizmust: „[E]rő vagy erőszak törvénytelen használata személyek vagy vagyontárgyak ellen azzal a céllal, hogy megfélemlítsék vagy korlátozzák a kormányt, a polgári lakosságot, vagy azok bármely részegységét politikai vagy társadalmi célok előmozdításában.”^ Míg a brit kormány a következőképpen fogalmaz:

„[N]agyfokú erőszak alkalmazása személyek, vagyontárgyak ellen, vagy ilyen erőszak használatával való fenyegetés, arra törekedve, hogy megfélemlítsék vagy kényszerítsenek egy kormányt, a lakosságot vagy a lakosság bármely csoportját, politikai, vallási vagy

\footnotetext{
Murányi Ignác József, Nemzeti Közszolgálati Egyetem Hadtudományi és Honvédtisztképző Kar, nemzetközi biztonság- és védelempolitika szakos hallgató.

Ignác József Murányi, University of Public Service, Faculty of Military Sciences, Department of International Security Studies, BsC student. E-mail: ignac.muranyi15@gmail.com

2 David A. Alexander - Susan Klein: The psychological aspects of terrorism: from denial to hyperbole. Journal of the Royal Society of Medicine, 98. (2005), 12. 557-562.

3 Farkas Johanna: A magányos merénylők radikalizálódása. Acta Humana, 4. (2016), 5. 17-31.

4 Marie-Helen Maras: A terrorizmus elmélete és gyakorlata. Budapest, Antall József Tudásközpont, 2016. 35.
} 
ideológiai célok elérése érdekében. A nagyfokú erőszak kifejezést úgy kell értelmezni, hogy az kiterjedjen a normál múködés súlyos megzavarására például számítógépes rendszerek vagy közszolgáltatások elleni támadásokkal." ${ }^{5}$

A terrorizmus spektruma nagyon széles skálán mozog. Találunk benne példákat a szélsőbaloldaltól a szélsőjobboldalig, a vallásostól a nem vallásosig, az erôsen szervezett, top-down döntéshozatalú, vagy épp decentralizált stratégiát használó csoportokat, ${ }^{6}$ valamint a különféle mentális zavarokkal rendelkező, illetve nem rendelkező egyéneket is. ${ }^{7}$

\section{A terrorizmus/terroristák alapvető pszichológiai jellemzői}

Közös pszichológiai motívuma ezeknek a csoportoknak viszont nem más, mint hogy megfélemlítés útján igyekeznek kikényszeríteni az adott állam vagy csoport - olykor célszemély - attitűd- és viselkedésváltozását, ezáltal közelebb kerülve legtöbbször politikai, ideológiai vagy gazdasági céljaikhoz.

Az erőszak tehát nem cél, hanem eszköz, amellyel a terrornak nevezett pszichológiai légkört kialakítják, ezáltal nyomást gyakorolva az általuk megtámadott célcsoportra. Emellett a hatás mellett az állandó félelemtől szított éberség, feszültség, bizalmatlanság légköre egyrészt dezorganizálja és gazdaságilag is nagyban kimeríti az adott közösséget. ${ }^{8}$ Másrészt nagymértékben kedvez a csoportok közötti további erőszaknak. A célközösség vagy ország megfelelő múködésének ellehetetlenülése, a lakosságra nehezedő terhek képesek tovább mélyíteni az esetleges belső viszályokat, és olyan faji, etnikai vagy vallási feszültségek kapnak lángra, amelyek tovább mélyítik az adott közösség destabilizációs folyamatát. ${ }^{9}$

Összefoglalva: minden terrorista alapvető célja, hogy megrendítse a társadalom fennálló szerkezetét, hogy ilyen módon arra kényszeríthessék, hogy a további pusztítás elkerülése érdekében fogadja el a követeléseiket. ${ }^{10}$ De miért is ilyen penetráns a terrortámadások által okozott félelem, annak ellenére, hogy az Our World in Data 2017-es felmérése szerint a világ összes haláleseteinek 0,05\% - a fejlettebb európai, óceániai és amerikai országokban pedig a halálesetek kevesebb mint 0,01\%-át - okozta „csupán” ?11 És vajon milyen következményei lehetnek egy esetleges jövőbeli terrorhullámnak? A választ a pszichológia nyújtja.

Maras (2016): i. m. 36.

John G. Horgan: Psychology of terrorism: Introduction to the special issue. American Psychologist, 72. (2017), 3. 199-204.

Raymond H. Hamden: Psychology of terrorists. Profiling and counter action. Boca Raton, CRC Press, 2019. 31-32.

8 Lippai Zsolt - Thieme-Eső Milán: A szállodák, mint „puha célpontok”. In Csaba Zágon - Szabó Andrea (szerk.): Közös kihivások-egykor és most. Budapest, MRTT Vám- és Pénzügyőri Tagozat, 2020. 159-182.

9 Lippai Zsolt - Thieme-Eső Milán: A szállodák elleni terrortámadások elkövetésének módszerei. Szakmai Szemle, 18. (2020), 2. 75-95.

10 Maras (2016): i. m. 54.

11 Hannah Ritchie et al.: Terrorism. Our World in Data, 2019. 
Először is beszéljünk magáról a terrorizmusról mint jelenségről. A kép, amely talán jól összefoglalná a fenomént az egy, a társadalom felett és között lebegő fantom lenne. Ott van, mégis sokszor láthatatlan és megfoghatatlan. Ismeretlen, névtelen és arctalan, amely legtöbbször az adott közösség humán és szimbolikus Achilles-sarkát veszi célba. Mindemellett logisztikai összeköttetéseiket nagy kihívás felkutatni, szervezeti felépítésük sokszínú, sokszor erősen decentralizált, önmúködő sejtek sokaságát alkotva önálló működésre képesek egy ideológia vagy cél által vezérelve. ${ }^{12}$ Motivációik sokszínúek, pszichológiai profiljuk szintén, a háttérfaktoroknak köszönhetően. ${ }^{13}$ Gyakori jellemzőik közé tartozik a torzított, abszolutista világnézet, szélsőséges, vagy velünk vagy ellenünk gondolkodás, amely az ellenség dehumanizálásával párosul. Ez a pszichológiai elegy meglepően hatékonyan képes az emberekbe kódolt emberölés elleni gátat felmorzsolni. Amit nem tekintünk embernek, sokkal könnyebb megölni. Ráadásul, ha egy erős vallási ideológián alapulnak a nézeteik, mint például az iszlám vallási radikálisok esetében, a halált nem félik, vagy másképp félik, mint az átlagember. Mivel a mennyben vár rájuk a jutalom. ${ }^{14} \mathrm{Az}$ önmagukat legtöbbször felszabadítóként vagy szent harcosokként identifikáló radikálisokra jól illik az a mondás, hogy: „Aki az egyiknek terrorista, az a másiknak szabadságharcos."15

\section{Terrorizmus a Maslow-piramis és az elhárító mechanizmusok tükrében}

A megtámadott közösségre mért pszichológiai hatást érdemes Abraham Maslow ${ }^{16}$ szükségletpiramisának tükrében megközelíteni. Ha megvizsgáljuk nagy hatású elméletét, akkor egy egymástól korántsem független, sokkal inkább egységes szükségletrendszert látunk. Csak az képes a maslowi piramis magasabb szintjeire lépni, akinek az adott szint alatt lévő szükségleteit megfelelő mértékben kielégítették.

A legalsó szint a legalapvetőbb igényeinket takarja: ilyenek többet között a víz, táplálék, oxigén iránti vágyunk. Tehát az alapvető túlélésünk alkotja a piramis alapját. Rögtön a fiziológiás szükségletek felett helyezkedik el - és amelyet a terroristák is megcéloznak - a biztonság és fizikai védettség iránti vágyunk. Ebből eredően, ha egy adott személy vagy épp egy társadalom nem érzi magát megfelelően biztonságban/védettnek, úgynevezett kötődési problémák lépnek fel, képes súlyos hatásokat mind individuális, mind kollektív szinten elszenvedni. ${ }^{17}$ Ugyanis,

\footnotetext{
2 Maras (2016): i. m. 96-114.

13 Farkas Johanna - Fogarasi Mihály: A bünelkövetés pszichológiai tényezői. In Haller József (szerk.): A bünöző elme. Budapest, Ludovika Egyetemi Kiadó, 2020. 151-185.

14 Randy Borum: Psychology of terrorism. Tampa, University of South Florida. 2004. 25, 34-35, 37-38, 49, 51-53, 58.

15 Stanley Weitzmann: Terorrizmus. Budapest, Magyar Könyvklub, 2005. 7.

16 Abraham Maslow: A theory of human motivation. Psychological Review, 50. (1943), 4. 370-396.

17 Farkas Johanna: A kötődés szerepe és jelentősége a személyiségfejlődésben. Határrendészeti Tanulmányok, 14. (2017), 3. 97-117.
} 
ahol a terror uralkodik az elmékben, ott ebböl eredően kevesebb pszichés energiánk marad az élet magasabb fokú megélésére. Ugyanis a terrorcselekményeket követő pánik hatására gátlódhatnak a magasabb szintű kognitív funkciók. Belső erőtartalékaink az úgynevezett elhárító mechanizmusok múködtetésére mennek el, amelyet az „én” mozgósít a szorongás redukálása céljából. Ezek a védelmi mechanizmusaink segítik az énünket abban, hogy megbirkózzon a ránehezedő nyomással. ${ }^{18}$ Viszont minél több pszichés erőforrás megy el múködtetésükre, annál kevesebb energia marad azokhoz a bizonyos magasabb szintekhez. Ilyen mechanizmus példájaként - a teljesség igénye nélkül - említhetjük az elfojtás jelenségét, amikor valamivel - jelen esetben a terrortámadással - kapcsolatos gondolatokat és érzéseket igyekszünk kiszorítani a tudatunkból. Az elfojtás az egyik legalapvetőbbnek mondható elhárító mechanizmusunk, és egy bizonyos fokig normálisnak mondható reakció, akármilyen jellegú minket ért stresszhatásra.

Mivel azonban a terrorizmus meglehetősen extrém szintü terhet helyez a megcélzott társadalom pszichés védelmi rendszerére - amellyel nem mindig és nem mindenki tud megfelelően megbirkózni -, ebből eredően nagyobb eséllyel indulnak be alacsonyabb szintű elhárító mechanizmusok. Ilyen például a tagadás jelensége, amely során az egyén(ek), ahogy nevében is benne van, tagadják, hogy egy adott esemény ténylegesen megtörtént. Ez a társadalmi fenomén például a 9/11-es amerikai terrortámadás után kimutatható volt. ${ }^{19}$ További példának okáért felhozhatjuk a regressziónak nevezett elhárító mechanizmust is, amely esetében korábbi fejlődési szintünkre csúszunk vissza, és egy önmagunkhoz képest redukáltabb viselkedési, gondolkodási és érzési formát kezdünk el tanúsítani. És mivel a terrorizmus legtöbbször egész nemzeteket vagy csoportokat céloz, ezért ez a folyamat képes teljes közösségekre kollektívan kiterjedni, súlyos károkat okozva az adott társadalom pszichés jólétében és fejlődésében.

\section{A terrorizmus szociálpszichológiai jellemzői}

A regresszió mellett mindenképp érdemes az eltolódás nevű elhárító mechanizmusát is számba venni, ha terror szociálpszichológiai következményeit firtatjuk. Mivel a megtámadott közösség legtöbbször egy out group, azaz egy külső csoport által elkövetett támadásként észleli a terrorcselekményt, a terroristák irányába érzett feszültség áttolódhat arra a szociális csoportra/etnikai közösségre, amellyel összefüggésbe hozzák a terroristákat. ${ }^{20}$ Erre számos példa volt Nyugat-Európában, ahol a bevándorlás következtében milliós nagyságrendű arab származású bevándorló/menekült érkezett, és ahol a terrorcselekmények után ők voltak azok, akik

\footnotetext{
18 Farkas Johanna - Borbély Zsuzsanna: Önismeret. In Haller József - Farkas Johanna (szerk.): Pszichológia a közszolgálatban I. Budapest, Dialóg Campus, 2018. 97-116.

19 Alexander-Klein (2005): i. m. 557-562.

20 Charles Carver - Michael F. Scheier: Személyiségpszichológia. Budapest, Osiris, 2005. 231-393.
} 
elszenvedték a megtámadott európai közösség tehetetlenségéből született haragot. Szociálpszichológiai szempontból ezt a fenomént a vikariáló bosszújelenség ernyője alá könnyedén beilleszthetjük. A vikariáló bosszú folyamán egy bizonyos csoport azon tagjai, akiknek a támadás közvetlenül kárt nem okozott, bosszúból megtámadják a bántalmazó csoport tagjait. Ez a folyamat nagyon könnyedén egyre meredekebben zuhanó erőszakos spirálba ránthatja az egész közösséget, ugyanis a terrorizmus által okozott félelem a gyúlölet melegágya, a gyülöletből pedig csoportok közötti további feszültségek és erőszakos cselekedetek születhetnek. A ciklus pedig kezdődik elölről, csak egyre intenzívebben. ${ }^{21}$ Ami ezt a jelenséget igazán veszélyessé teszi az az, hogy elég egy apró szikra, és robbanhat az európai lőporoshordó, amely a - magát másokra erőszakoló - német Willkommen-politikának köszönhetően teli van potenciális, egymást kölcsönösen gerjesztő radikális robbanóanyaggal. Mindkét oldalról. Szomorú tény, de érdemes tudatosítani, hogy a dzsihád agresszív, eltorzult formái jelen vannak szerte a világban, köztük kontinensünkön is.

\section{A dzsihád valódi jelentése}

A tisztánlátás végett viszont érdemes néhány dolgot a dzsiháddal kapcsolatban tudatosítani, amiben Abdul-Fattah Munif magyar-jemeni származású Korán-kutató írása sokat segíthet a témában érdeklődőknek. A dzsihád alapjelentését tekintve a következő: A dzsihád szó az arab dzs-h-d igegyökből ered. A dzsehede alapige azt jelenti, hogy fáradozott, erőt fejtett ki, ezért a dzsuhd névszó a modern arab nyelvben a kifejtett fizikai, szellemi és mechanikai erőt, energiát jelöli. ${ }^{22}$ Tehát a közhiedelemmel ellentétben nem jelent szent háborút vagy ártatlan civilek elleni harcot. A dzsihád alapvetően erőfeszítést, küzdelmet jelent. A mudzsáhid pedig az erőfeszítést végző, küzdelmet folytató személy. Tehát innen ered a muzsahed, szent harcos kifejezés, amelyet a radikális iszlám vallási irányzatok előszeretettel alkalmaznak. Továbbá az iszlám jogtudósok a háborút nem szokták szentnek nevezni. Pusztán jogosnak vagy igazságosnak, ha honvédelemről, szabadságharcról vagy felszabadításról van szó. Az viszont más kérdés, hogy akárcsak a történelem során, a mai napig rendszeresen hivatkoznak a dzsihádra mint az általuk alkalmazott erőszak eszmei és erkölcsi hátterére. A tisztánlátás végett viszont érdemes megemlíteni, hogy teológiai szempontból korántsem csak egyféle dzsihádról beszélhetünk, hanem négyről, és azon belül is megkülönböztethetünk háromféle külső és egy belső dzsihádot. Az első, a legnagyobb dzsihád a „szív dzsihádja”, avagy a „lélek dzsihádja”, arabul mudzsáhedet al-nafsz, amely a belső gonoszság elleni spirituális erőfeszítést jelenti. De a belső dzsihád ernyője alá illeszthetjük az elme dzsihádját is, arabul idzstihádot, amely elsősorban a vallásjogtudósok intellektuális és szellemi erőfeszítését jelenti,

21 Eliot R. Smith - Diane M. Mackie - Heather M. Claypool: Szociálpszichológia. Budapest, ELTE Eötvös, 2016. 678679.

22 Abdul-Fattah Munif: A dzsihád valódi jelentése a vallástudományban. PR Herald, 2020. 03. 26. 
amely a nem egyértelmű vallási kérdések megoldására irányul. A maradék három dzsihád a külvilág irányába fordul. A második a környezet iránti türelemre és jámborságra int, amely kiterjed a családra, a feleséggel és gyerekekkel való kedves bánásmódra, sőt magában foglalja többek között a szomszédság és a nem muszlimok irányába történő türelmet is. A harmadik a tollal és szóval történő erőfeszítésre hívja fel a figyelmet a társadalmi betegségekkel szemben, a közjó érdekében. Elősegíteni a „helyes viselkedést” és tanácsot adni azoknak, akik letértek a követendő útról. És végül van a vagyonnal és fegyverrel történő dzsihád, a „kard dzsihádja”. ${ }^{23}$ A Korán így fogalmaz:

\begin{abstract}
„Engedélyt kaptak [a harcra] azok, akik ellen harcolnak, mivel ők jogtalanságot szenvedtek el, és Allah bizony képes az ő megsegítésükre. Akiket igaztalanul úztek el a lakhelyeikről csupán azért mivel azt mondták: Allah a mi Urunk! S ha Allah nem tartotta volna vissza az embereket - egyiket a másik által -, bizony leromboltattak volna szerzetescellák, templomok, zsinagógák, mecsetek, ahol gyakran említtetik az Allah neve. Allah bizony megsegíti azokat, akik őt segítik. Allah felettébb erős és hatalmas." ${ }^{24}$
\end{abstract}

Az iszlám vallási radikális csoportok ilyen és ehhez hasonló mondatokat kiragadnak a Koránból, saját eltorzított módjukon értelmezik, majd arra használják, hogy erkölcsi és teológiai értelemben is szabad utat generáljanak maguknak egy olyan háborúhoz, amely során mindkét oldalra csak szenvedés vár. A Koránból valóban egyértelműen kiderül, hogy az iszlám elismeri a háború szükségességét és jogosságát bizonyos esetekben, például ellenséges katonai agresszió, megszállás vagy egy zsarnoki hatalom uralkodásának veszélye esetén. A harc azonban nem lehet öncélú vagy igazságtalan. Az iszlám vallás háborús helyzetre vonatkozó szabályai még a harctérre is kiterjednek. Ugyanis előírja, hogy küzdelem esetén is igazságos bánásmódot kell alkalmazni, és kizárólag a fegyverrel támadó ellenséggel szemben lehet harcolni. Tehát az iszlám harci morálba semmilyen formában nem illik bele az, hogy vallási radikálisok ártatlan civileket mészároljanak. Mérvadó muszlim vallástudósok is kifejtik, hogy mélyen elítélik az ilyen és ehhez hasonló cselekedeteket, ráadásul szégyent is hoznak vele az iszlámra, amely eredendően a béke és az elfogadás vallása lenne. A muszlimoknak sokkal inkább arra kell törekedniük, hogy elkerüljék az összecsapásokat, és ha van rá mód, inkább a békés megoldást kell választaniuk: „Ó ti, akik hívők vagytok! Lépjetek be a békességbe mindannyian, s ne kövessétek a sátán nyomdokait! Bizony ő nektek nyilvánvaló ellenségetek.”25

A szenvedés, amelyet a terroristák háborúja - és a mi háborúnk a terrorizmus ellen - generál egyáltalán nincs összhangban a Szeretet Egy Igazságával, amelyet a világ vallásai próbálnak megragadni, csupán más nevekkel, más úton és más eszközökkel. Fontos kiemelni, sőt, talán emlékeztetni magunkat, hogy nem az iszlámmal

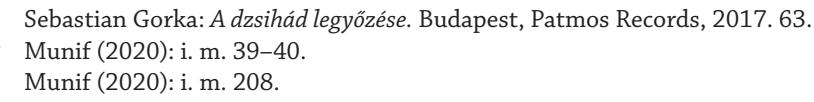


áll szemben a nyugati világ, hanem azokkal, akik az iszlámot kiforgatva arra használják, hogy elborult elméjük és a gyülölettől beteg lelkük végre szabad utat engedhessen jellembéli hibáiknak. Agressziójuknak, múltbéli sérelmeiknek, uralkodási vágyuknak, a nők és gyerekek tárgyként való kezelésének, vagy épp a „hitetlenek” lemészárlásának. Fontos kiemelni, hogy nem az iszlámmal áll harcban Európa és a nyugati világ, hanem az iszlámot rosszul értelmező és nem megfelelően magukévá tevő eltorzult jellemek sokaságával. Ők azok az egyének, akiket biztonságpolitikai szempontból maximális éberséggel monitorozni, és ha szükséges, a lehető leghatékonyabban hatástalanítani kell. Ugyanis, ha nem figyelnek Európa döntéshozói, akkor az eltorzult és sajnos sokszor fertőző vallási világképük képes lesz nagyon könnyedén azzá a bizonyos gyulladást okozó szikrává válni, amely szociálpszichológiai lángtengerré változtathatja a kontinenst. A szikra pedig bármi lehet. Egy egyszerú pengétől vagy LIWA (light infantry weapon attack) könnyű gyalogsági fegyveres támadástól, az egykori 1984-1995 között aktívan múködő Aum Sinrikjo által használt szofisztikáltabb szaringáztámadásig számos dolog szóba jöhet a jövőben. De emellett kiemelt figyelmet kell fordítani a potenciális kibertámadásokra, valamint WMD (weapons of mass destruction) tömegpusztító fegyverek és CBRN (chemical, biological, radiological, nuclear) kémiai, biológiai, radioaktív, nukleáris fegyverekből eredő veszélyek elhárítására is. ${ }^{26} \mathrm{Az}$ emberi kreativitás rendkívül határtalan tud lenni, a történelem pedig számos példát tud felmutatni, főleg olyan dolgokban, amelyeknek határt kellene szabnia.

\section{A média szerepe a terrorcselekmények során}

Viszont nem elég, ha csupán végrehajtják a terroristák az akciójukat. Különféle kommunikációs csatornákon el is kell juttatniuk azt a nagyobb célközönség felé. Itt érdemes megemlíteni, hogy az Iszlám Állam (ISIS) forradalmasította a modern média fegyverként történő használatát a terrorizmusban. Profi szinten, a legkülönfélébb kommunikációs platformokon, kiemelt hangsúllyal az interneten és a közösségi médiában, terjesztették az ideológiájukat, illetve a fenyegetéseiket. ${ }^{27} \mathrm{~A}$ terroristák viszont nem csak a saját kommunikációs platformjaikat használják. Sajnos szomorú tény, de kiválóan rájátszanak a fejlettebb országok médiájának alaptermészetére, amely a nézettség és a kattintások mértékében méri a sikerét, nem pedig abban, hogy amit közvetítenek, annak vajon milyen hatása lesz az adott társadalomra. Minél nagyobb arousalszintet okoz egy hír, ez lehet akármilyen jellegű, annál nagyobb valószínűséggel figyel oda rá az adott személy. Ebből eredően több klikk, több néző, több hirdetést és reklámot látnak az adott platformon. Tehát több pénzt generál. Egyszerű logika. ${ }^{28}$ Tehát amíg „trendi” és megfelelő nézettségi forgalom származik

\footnotetext{
26 Maras (2016): i. m. 105-109, 121-122, 140-151, 158-165, 450, 521.

27 Moran Yarchi: ISIS's media strategy as image warfare: Strategic messaging over time and across platforms. Communication and the Public, 4. (2019), 1. 53-67.

28 Ryan Holiday: Trust me, I'm lying. New York, Portfolio/Penguin, 2012.
} 
belőle, addig öntik az emberek nyakába a terrort, ezáltal oroszlánrészt vállalva a társadalom megfélemlítésében. Szándékosan használtam a trendi szót, ugyanis, ha valaki visszatekint az idôben 2015-2016 környékére, akkor láthatja, hogy az ISIS sokadik terrortámadását Európa ellen egyre kevesebb ideig sugározták a médiában. Ugyanis a lakosság már kezdett hozzászokni, már nem volt akkora hírértéke. Szemben az első párizsi lövöldözésekkel, amelyek hetekig vezető pozícióban voltak a híradásokban. Szomorú tény, de a terroristák legnagyobb fegyvere a média. Ráadásul annak az országnak a médiája, amelyet megtámadnak. A média „az emberek tájékoztatása" címszó alatt az ellenség legerősebb fegyverévé válik. Ez a bizonyos „legerősebb fegyver” ugyanis nem az AK-47, hanem a pszichológia. Mert ártatlanok tucatjait le lehet lőni, de százezrek, sőt milliók felett már nem a gépfegyver fog uralkodni, hanem a pszichés hatás, amit kivált. Ebből eredően voltak is viták a múltban, hogy vajon cenzúrázni kellene-e a médiát a terrortámadások után.

Margaret Thatcher 1979 és 1990 között hatalmon lévő angol miniszterelnök a cenzúra irányába húzott, és így érvelt: A terroristák ki lennének éhezve a „nyilvánosság levegője után" és abbamaradnának a támadások, ha a média nem közvetítené azokat. Hasonló nézetet vall Benjamin Netanjahu is, aki így fogalmazott: „A nem közzétett terrorista akciók olyanok lennének, mint a zuhanó fa a néma erdőben." Ez ellen foglalt állást Lawrence K. Grossman, az NBC egykori elnöke. Szavait idézve: „Nem tapasztaltam semmiféle bizonyítékot arra vonatkozóan, hogy a nagyközönségre valaha is hatott volna a terrorista propaganda, vagyis a tévéképernyőn keresztüli zsarolás." ${ }^{29}$ De ma már kétségeket kizáróan tudjuk, hogy igenis nagy hatása van a médiának a terroristák ügyének elővitelében. Az igazság valahol a két álláspont között lehet, de az biztos, hogy a szabályozási kísérletek ellenére, a modern média a jelenlegi formájában kritikán aluli módon hozzájárulhat az emberek megfélemlítéséhez. Albert Einstein egyik számtalanszor idézett gondolata: „Azt nem tudom, hogy a harmadik világháborút mivel fogják vívni, de azt biztosan tudom, hogy a negyediket botokkal és kövekkel." Habár nem szokás az óriások szavait megkérdőjelezni, én most mégis megtenném. A jövő háborúja láthatatlan lesz, és nem fog másért zajlani, mint az emberek elméjéért. Nem az olaj vagy az arany a legnagyobb kincs, amit uralhatunk, hanem a saját elménk. Vagy épp mások elméje. Mert ha valakinek a pszichéjét uralják, annak uralják mindenét. Az olajával, aranyával, az összes fegyverével és erőforrásával együtt. Eme gondolatot hadd támassza alá az a történelmi tény, hogy a hidegháború, az összetett nemzetközi politikai, gazdasági, katonai és titkosszolgálati intézkedések mellett - végső soron - a fejekben dőlt el. Mivel nem volt más, mint ideológiák harca. Név szerint az amerikai típusú demokrácia, a szovjet kommunizmus ellen. Mind a kettő ott terjedt el, ahol az emberek pszichéje befogadóvá vált a világnézetükre. Vagy épp, ahol ráerőltették azt másokra. A terroristák ideológiája is épp ezt a logikát követi. ${ }^{30}$ Egy láthatatlan betegség, a vallási, sôt

\footnotetext{
Stanley Weitzmann: Terrorizmus. Budapest, Magyar Könyvklub. 2005. 20-21.

30 Sebastian Gorka: A dzsihád legyőzése. Budapest, Patmos Records, 2017.
} 
akármilyen jellegű radikalizmus eszméje ott ver tanyát, ahol a gyülöletből, haragból és a tudatlanságból eredően képes megfertőzni az egyéneket. És amely a „hitetleneket”, vagy a „nem helyesen gondolkodókat” félelemmel fertőzi tovább. A mi döntésünk, hogy a kontrollt átengedjük-e, és feláldozzuk-e szabadságunkat a félelem oltárán. Veszélyesek a modern láncok, ugyanis láthatatlanok. De a jó hír, hogy a mi döntésünk, hogy nyakunkba vesszük-e őket.

\section{Zárógondolatok}

Vajon mégis mi fogja legyőzni a terrorizmust? A gyülölet, a tudatlanság és a félelem, amelyből a radikalizmus táplálkozik, végső soron egyedül szeretettel és tudással győzhető le. A gyülölet hidrájának tehát nem a folyton újrasarjadó fejét érdemes célba venni, hanem a szívét, amely a fent említett érzésekből táplálkozik. Mert amíg a szíve dobog, addig mindig lesz feje. Hol nácizmusként, hol al-Káida vagy ISIS néven lát majd napvilágot. Épp ezért szükséges egy olyan stratégiaváltás, amely a rombolás helyett hidakat épít a történelem sebhelyes szakadékjai fölé. Ezáltal váltva meg a jelenünket. Ugyanis az oly sokak által megjósolt virágkor nem a messzi jövőben van, hanem a jelenben, csupán karnyújtásnyira. Egy szeretetnyi karnyújtásra. És amint a világ emberei ismét rájönnek, hogy a legnagyobb ellenség mindig bennünk lakozik, akkor valóban elérhetünk valamit. Addig marad a másikra mutogatás. A megoldás: kevesebb bomba, több pszichológia.

\section{FELHASZNÁLT IRODALOM}

Alexander, David. A. - Susan Klein: The psychological aspects of terrorism: from denial to hyperbole. Journal of the Royal Society of Medicine, 98. (2005), 12. 557-562. Online: https://doi. org/10.1177/014107680509801222

Borum, Randy: Psychology of terrorism. Tampa, University of South Florida, 2004.

Carver, Charles S. - Michael F. Scheier: Személyiségpszichológia. Budapest, Osiris. 2006.

Farkas Johanna: A magányos merénylők radikalizálódása. Acta Humana, 4. (2016), 5. 17-31.

Farkas Johanna - Borbély Zsuzsanna: Önismeret. In Haller József - Farkas Johanna (szerk.): Pszichológia a közszolgálatban I. Budapest, Dialóg Campus, 2018. 97-116.

Farkas Johanna - Fogarasi Mihály: A bűnelkövetés pszichológiai tényezői. In Haller József (szerk.): A bünözö elme. Budapest, Ludovika Egyetemi Kiadó, 2020. 151-185.

Farkas Johanna: A kötődés szerepe és jelentősége a személyiségfejlődésben. Határrendészeti Tanulmányok, 14. (2017), 3. 97-117.

Gorka, Sebastian: A dzsihád legyőzése. Budapest, Patmos Records, 2017.

Hamden, Raymond H.: Psychology of terrorists. Profiling and counter action. Boca Raton, CRC Press, 2019. Online: https://doi.org/10.4324/9781315156750

Holiday, Ryan: Trust me, I’m lying. New York, Portfolio/Penguin, 2012.

Horgan, John G.: Psychology of terrorism: Introduction to the special issue. American Psychologist, 72. (2017), 3. 199-204. Online: https://doi.org/10.1037/amp0000148 
Lippai Zsolt - Thieme-Eső Milán: A szállodák, mint „puha célpontok”. In Csaba Zágon - Szabó Andrea (szerk.): Közös kihívások - egykor és most. Budapest, MRTT Vám- és Pénzügyőri Tagozat, 2020. 159-182. Online: https://doi.org/10.37372/mrttvpt.2020.1.9

Lippai Zsolt - Thieme-Eső Milán: A szállodák elleni terrortámadások elkövetésének módszerei. Szakmai Szemle, 18. (2020), 2. 75-95.

Maras, Marie-Helen: A terrorizmus elmélete és gyakorlata. Budapest, Antall József Tudásközpont, 2016.

Maslow, Abraham: A theory of human motivation. Psychological Review, 50. (1943), 4. 370396. Online: https://doi.org/10.1037/h0054346

Munif, Abdul-Fattah: A dzsihád valódi jelentése a vallástudományban. PR Herald, 2020. 03. 26. Online: http://prherald.hu/a-dzsihad-valodi-jelentese-a-vallastudomanyban/

Ritchie, Hannah - Joe Hasell - Cameron Appel - Max Roser: Terrorism. Our World in Data, 2019. Online: https://ourworldindata.org/terrorism

Smith, Eliot R. - Diane M. Mackie - Heather M. Claypool: Szociálpszichológia. Budapest, ELTE Eötvös, 2016.

Weitzmann, Stanley: Terorrizmus. Budapest, Magyar Könyvklub, 2005.

Yarchi, Moran: ISIS's media strategy as image warfare: Strategic messaging over time and across platforms. Communication and the Public, 4. (2019), 1. 53-67. Online: https://doi. org/10.1177/2057047319829587

\section{ABSTRACT}

\section{In the Shadow of Terror}

Ignác József MURÁNYI

In my current essay, I intended to highlight the potential psychological and social psychological effects of terrorism, especially Islamic radical terrorism. The topic was engaged from the perspective of the Maslow's hierarchy of needs, but the potential psychological defence mechanism activated by terrorist acts and their potential effects on the European society were also covered. A brief description of the ideology of jihad, the common psychological traits and motivations of terrorist groups was added too, along with their organisational characteristics and the role of the modern media. The essay is closed by a short personal thought.

Keywords: terrorism, psychology, jihad, social psychology 